\title{
The University Trial Garden as a Tool for Evaluating and Introducing New Plant Materials
}

A.M. Armitage and Meg Green

Additional IndeX words. annuals, evaluations, new crops, perennials

Summary. The University of Georgia trial garden has been in existence since 1982, and the method of evaluation and distribution of taxa has evolved over the years. Annual and perennial taxa are evaluated systematically, over the entire season, providing season-long summaries for each one. Annuals are evaluated every 2 weeks, and scores are based on plant performance, including foliar health, flower numbers and the appearance of disease and insect damage. Perennials are evaluated similarly, however flowering time, flowering persistence and height in the landscape are also noted. Summaries for each taxon are presented in tabular and graphic form. Many new crops have been evaluated and introduced to the floriculture industry. New crops are placed in the horticulture gardens and evaluated by garden personnel and by commercial growers and landscapers. Plants have been distributed free of charge to propagators and growers, resulting in rapid market acceptance of successful taxa.

university trial garden can be a source of credibility, funding
and pride for a department, however, a garden can also be an
inefficient use of resources unless the objectives of the garden are clearly defined and justified. Many objectives are attainable, however evaluation of crops and publication of crop performance are the minimum objectives. Preferably, the trial garden should be accessible to students, so that teaching may also be accomplished. The benefits of a well-maintained trial garden for teaching is obvious, but are secondary to the research and outreach goals of the garden. A trial garden is of limited value to those outside the university if data are not made available to as wide a range of clientele as possible, including retailers, growers and extension personnel both nationally and regionally as well as supporters of the garden. While the trial garden's main functions should be research and plant evaluation, introduction of new crops may also be possible, even in the absence of a plant breeder.

\section{The garden as a tool for evaluation, using the University of Georgia Horticulture Garden as an example}

From its inception, it was decided that the University of Georgia Horticulture Garden would primarily be a trial garden, and that evaluation of crops and publication of the data would be priorities.

Department of Horticulture, University of Georgia, Athens, GA 30602.

The cost of publishing this paper was defrayed in part by the payment of page charges. Under postal regulations, this paper therefore must be hereby marked advertisement solely to indicate this fact.

${ }^{1}$ Associate professor, Department of Horticulture, 101 Funchess Hall, Auburn University, AL 36849. 
To bring credibility to the crop evaluations, a system was put in place to provide long term evaluation of crops therein.

Annuals. Plants are started from seeds or as vegetative cuttings, grown in the greenhouse according to accepted production procedures, and placed in the University of Georgia (UGA) trial gardens between 15 Apr. to 1 May. Plants are placed in raised beds, baskets or containers containing compost and organic soils. About 15 plants of each taxon are planted in the beds, but fewer are planted in baskets and containers throughout the garden. All plants are planted in blocks but insufficient room is available to replicate blocks. They are fertilized, subirrigated or hand watered as needed and maintained according to accepted principles of maintenance.

Evaluation. In the summer trials, landscape performance is noted based on selected plant characteristics such as

\section{Alfa Mixed}

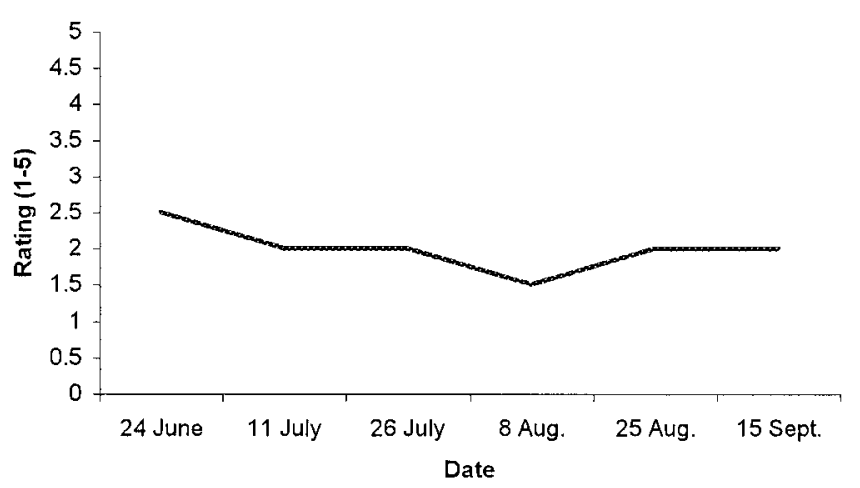

All Round White

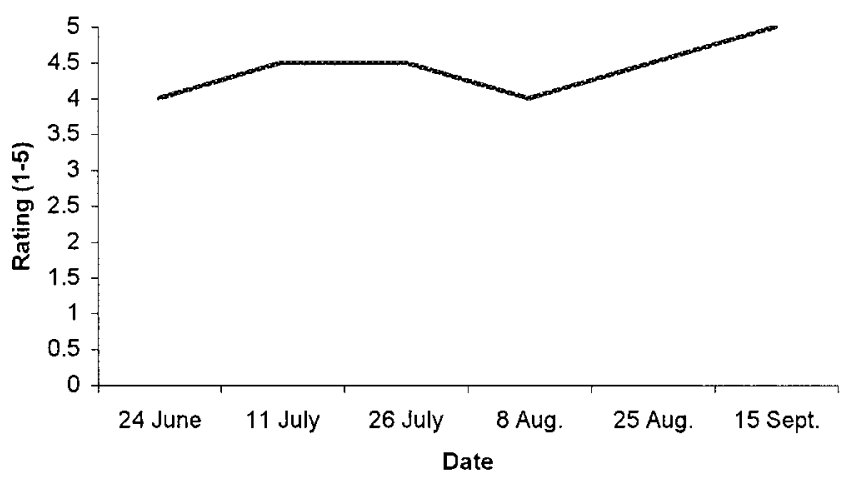

All Round Pink

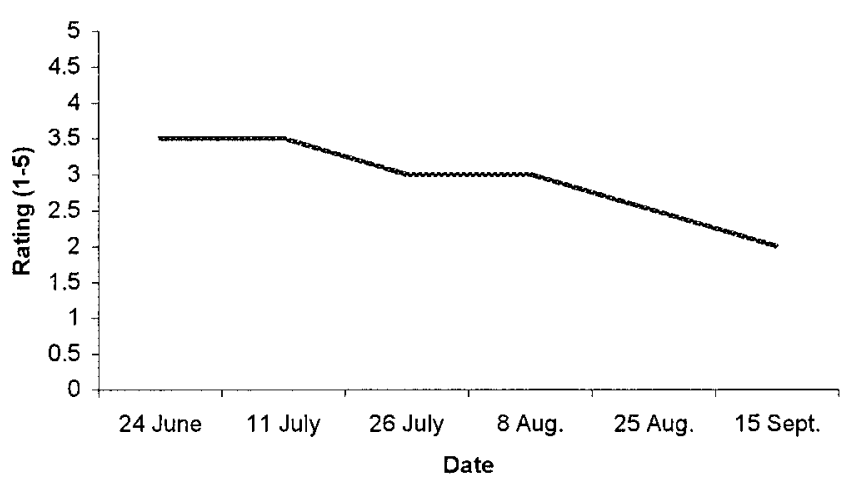

Ambassador Bicolor

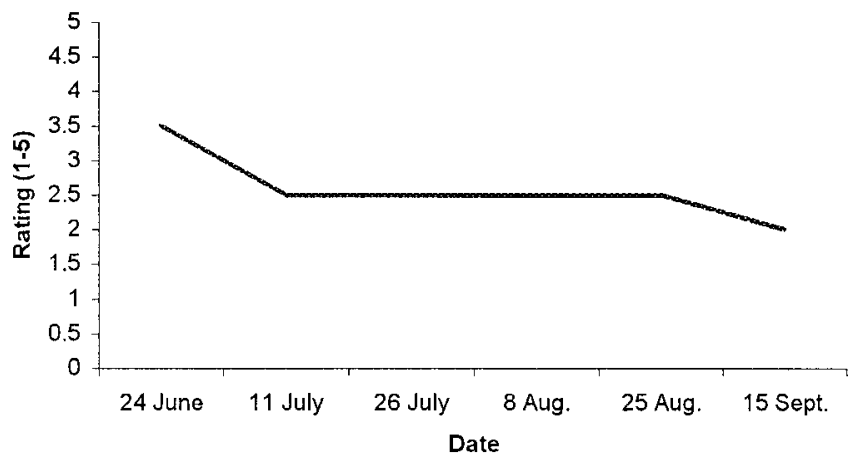

All Round Dark Rose

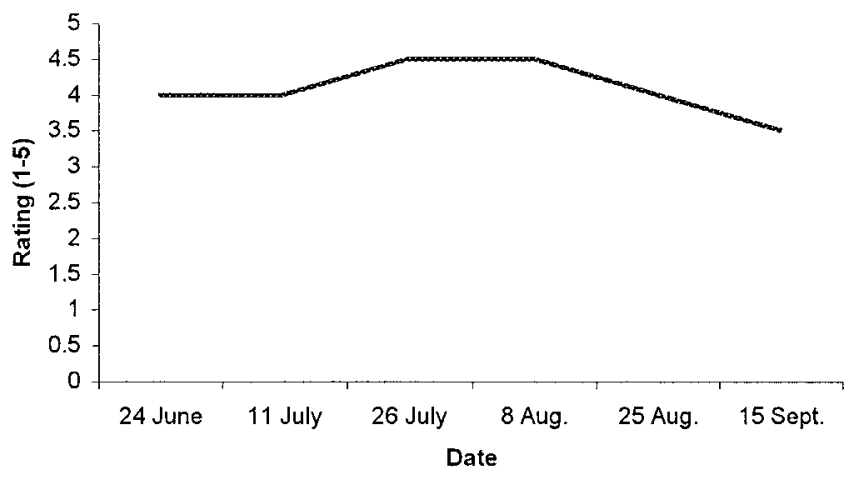

All Round Rose

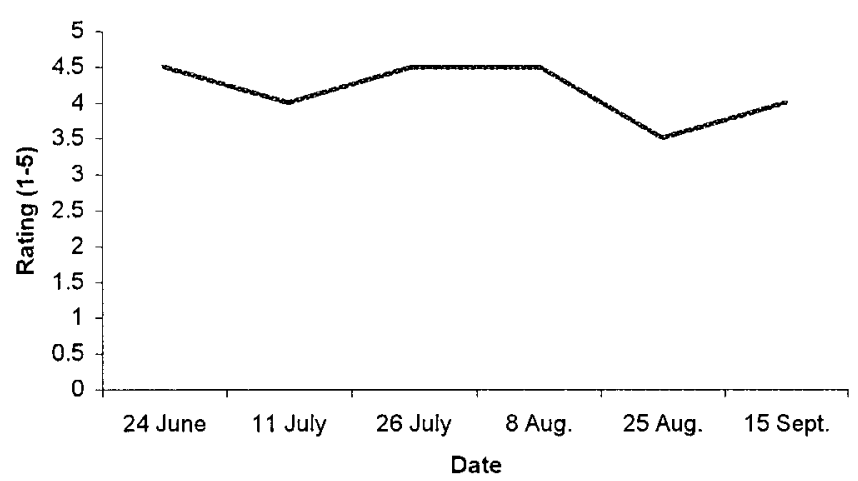

Fig 1. Time-performance ratings from 1 to 5 ( 5 being optimum) based on visual assessment of selected plant characteristics using six cultivars of wax begonia (Begonia semperflorens-cultomm) as examples. Seeds provided by Daehnfeldt Seed Co., Castroville, Calif. 
Table 1. Comparison of seasonal garden performance of wax begonia (Begonia semperflorens-cultomm) cultivars of the same flower color. Rating $5=$ excellent performance, 1 = poor performance.

\begin{tabular}{llc}
\hline Flower color & Cultivar & Rating \\
\hline \multirow{2}{*}{ Pink } & Ambassador Soft Pink & 4.2 \\
& Stara Pink & 4.2 \\
& Inferno Pink & 3.7 \\
& Senator Pink & 3.8 \\
All Around Pink & 2.9 \\
White & All Around White & 4.3 \\
& Inferno White & 3.9 \\
& Eureka White & 3.3 \\
& Ambassador White & 2.3 \\
& Stara White & 2.9 \\
\hline
\end{tabular}

Table 2. Comparison of seasonal garden performance of the carpet series of hybrid petunias (Petunia $\times$ bybrida). Rating $5=$ excellent performance, $1=$ poor performance.

\begin{tabular}{lcc}
\hline Cultivar & Rating & Ht (cm) \\
\hline Pink Carpet & 4.0 & 33.7 \\
Bright Red Carpet & 3.9 & 22.7 \\
White Carpet & 3.7 & 28.0 \\
Carpet Blue & 3.4 & 27.0 \\
Carpet Sky Blue & 2.7 & 27.7 \\
Rose Carpet Improved & 2.9 & 16.3 \\
\hline
\end{tabular}

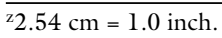

Table 3. Georgia Garden Gold Medal Winners, 1998-99.

\begin{tabular}{lll}
\hline Common name & Scientific name & Cultivar \\
\hline 1998 & & \\
Begonia & Begonia (hybrid) & Dragon Wing \\
Celosia & Celosia argentea & New Look \\
Fuschia & Fuschia hybrid) & Cascading Angel's Earrings \\
Wishbone flower & Torenia fournieri & Summer Wave Blue \\
Zinnia & Zinnia elegans & Profusion Cherry \\
1999 & & \\
New guinea impatiens & Impatiens $\times$ hawkeri & Petticoat Fire \\
Petunia & Petunia $\times$ bybrida & Tidal Wave Cherry \\
Petunia & Petunia $\times$ bybrida & Surprise Lavender \\
Purslane & Portulaca oleracea & Yubi Summer Joy Rose \\
Persian shield & Stobilanthes dyerianus & --- \\
\hline
\end{tabular}

insect resistance, disease resistance, uniformity of population, spread, number of flowers and overall foliage leaf health. Based on a visual assessment of those characteristics, a single numerical rating from 1 to 5 ( 5 being optimum) is recorded for each taxon. The data are initially collected 2 weeks after installation and every 2 weeks thereafter until about 1 Oct. At the end of the season, time-performance graphs are prepared (Fig. 1). Average height of each taxa is measured at maturity and also included (data not shown).

The time-performance figures demonstrate the season-long performance of each taxon, and illustrate the strengths and weaknesses based on time of season. They also illustrate the differences among cultivars based on seasonlong evaluation, allowing comparison within cultivars as well as within species.

Based on the data, tables are prepared to highlight cultivars within a species. Three are particularly important. Taxa with highest overall performance for a particular color (Table 1), performance within a series (Table 2 ) and taxa which exhibited the highest level of performance in the garden, re- gardless of color or genus (Table 3 ) are presented. Tables 1 and 3 are referred to as Best of the Best and Georgia Garden Gold Medal Plants, respectively. These summary tables are some of the most important datain the evaluation scheme, particularly for those not interested in studying every graph.

Perennials. Plants are received as prefinished material in a variety of container sizes, and are placed in the garden in October or March to April, depending on when they are received. Plants are fertilized, subirrigated or hand watered as needed throughout the evaluation process.

Evaluation. Perennial material is evaluated for specific characteristics such as flower color, insect resistance and disease resistance. Based on a visual assessment of those characteristics, a single numerical rating from 1 to 5 ( 5 being optimum) is recorded for each taxon. Actual dates for beginning of flowering, peak flowering time, last flower date and mature height are also recorded. Data are collected only when flowers are present, and generally collected for 3 years or for the life of the plant if less than 3 years. All data are presented, along with a photo and comments concerning plant performance by the evaluators. Based on the overall rating, performance of perennial species is summarized into performance categories, from excellent, rating of 4.5 to 5.0 , to poor, rating $<2.0$ (Table 4 ).

The data for both annuals and perennials are reported at the end of the season, and published in book form (Armitage et al., 1999) or on the Internet (Armitage, 2001). All data since 1999 have been reported on the Internet only.

\section{The garden as a tool for plant introductions}

No plant breeder was available to assist in the UGA effort, therefore a plant introduction program was not an original objective of the garden. At present, however, plant introduction is an integral part of the trialing program and has yielded significant benefits to the garden and to the industry. Numerous plants have been introduced (Table 5 ) but only three case histories will be discussed in this paper.

Case 1. 'Homestead Purple' verbena (Verbena). Plants were discovered in an old homestead between Athens and Atlanta, Ga., in March 1991 by the author and Michael Dirr (Armitage, 
Table 4. Summary of perennial taxa performance during the 1997 growing season. Rating $5=$ excellent performance, $1=$ poor performance. Performance is directly proportional to performance rating.

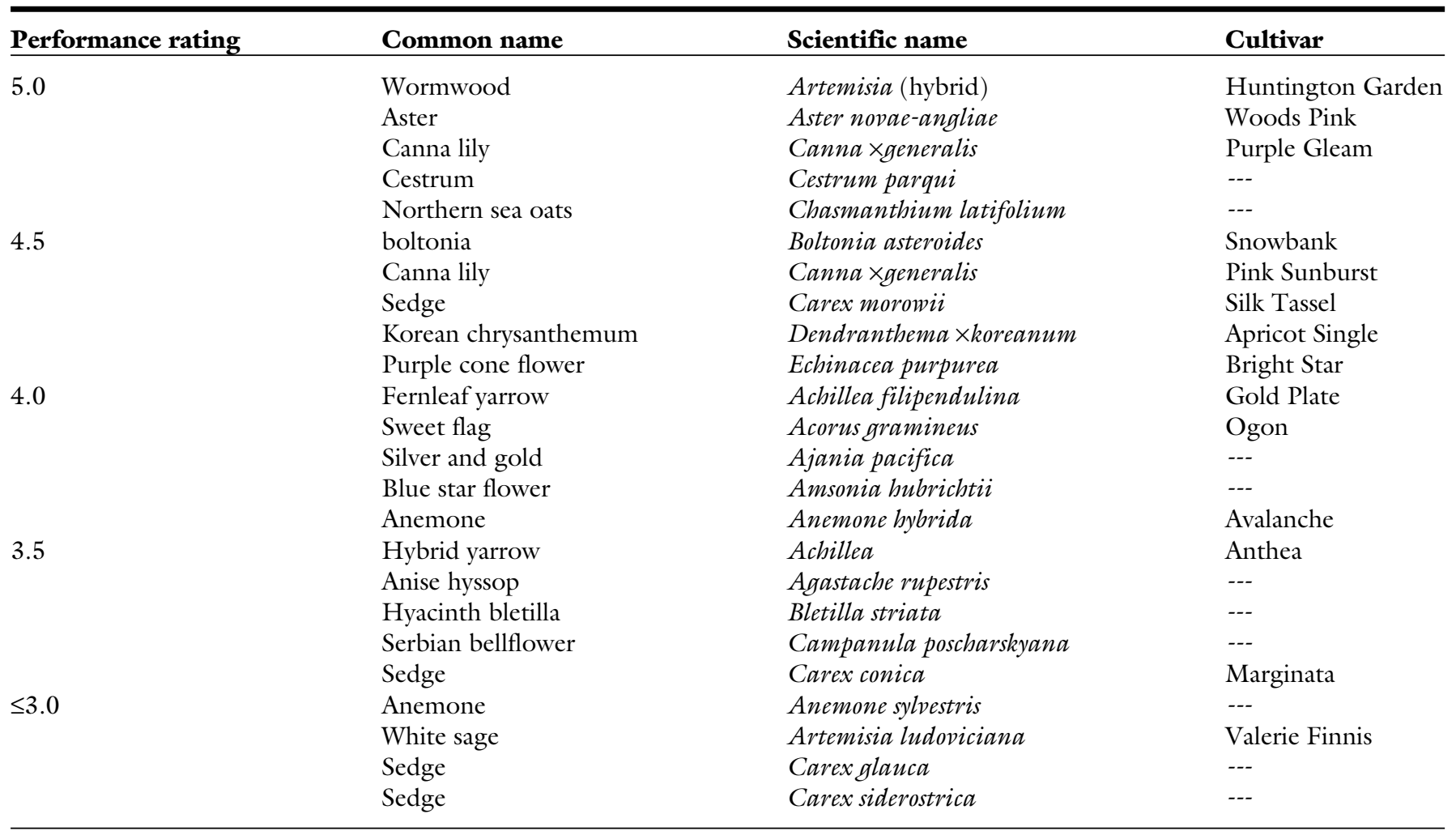

Table 5. Plant introductions from the University of Georgia Horticulture trial garden, 1991-00.

\begin{tabular}{lll}
\hline Common name & Scientific name & Cultivar \\
\hline Climbing bleeding heart & Dicentra scandens & Athens Yellow \\
Lantana & Lantana camara & Athens Rose \\
Sweet potato & Ipomoea batatas & Margarita \\
Plectranthus & Plectranthus amboinicus & Athens Gem \\
Rosemary & Rosmarinus officinalis & Athens Blue Spires \\
Scabious & Scabiosa & Lemon Sorbet \\
Coleus & Solenostemon scutellarioides & Sunlover Series (seven cultivars) \\
Princess flower & Tibouchina urvilleana & Athens Blue \\
Vervain & Verbena canadensis (hybrid) & Homestead Purple \\
\hline
\end{tabular}

1992). Seven cuttings were rooted in the UGA greenhouse and three plants were placed in the trial gardens in May 1991. The policy of the garden was to allow commercial growers who visited during the open house the opportunity to take cuttings of plants they felt were desirable. Cuttings were taken by a number of growers throughout the summer season of 1991 and grown commercially. The first plants of the verbena were sold in Georgia and the southeast in Spring 1992 under the name 'Homestead Purple'. In 3 years, 'Homestead Purple' was a popular verbena in the United States, and subsequently, plants have been sold in northern Europe and Japan. Prior to the introduction of
'Homestead Purple,' most verbenas used in the landscape trade were seed-propagated cultivars of garden verbena ( $\mathrm{Ver}$ bena $\times$ bybrida), sold as bedding plants similar to french marigolds (Tagetes patula) and wax begonias (Begonia semperflorens-cultorum). The success of 'Homestead Purple' verbena was a major impetus to development of the many cultivars of vegetatively propagated verbenas on the market today (J. Rader, personal communication).

Case 2. Sunloving coleus (Solenostemen scutellarioides). About 15 unnamed cuttings of coleus were provided by Butch Ferree of the UGA extension service. Plants were grown in the greenhouse and the trial gardens in
Spring 1994. In Spring 1994, seven taxa were named and introduced under the name Sunlover Series (Armitage, 1994). They have since become known as Sunloving coleus. Cuttings were taken by a number of growers throughout the summer season of 1994 and grown commercially. Plants were first sold under the Sunlover Series label in the southeastern U.S. in Spring 1995. As a result of the publicity concerning the series (Armitage, 1994, 1995), an additional series of coleus was introduced to the garden by George Griffith of Hatchett Creek Nursery, Gainesville, Fla. Plants were evaluated and named the Solar series, and sold by Hatchett Creek in Spring 1995. Numerous sun loving coleus have been introduced since the emergence of the Sunlover Series, and more continue to become available to the trade.

Case 3. 'Margarita' sweet potato (Ipomoea batatas). A single plant was provided in Fall 1995 by Hunter Stubbs of Raleigh, N.C. The plant was named 'Margarita' by Stubbs, placed in the garden in Spring 1996 and evaluated that season. Cuttings were taken by a number of growers throughout the summer season of 1996 and were first sold commercially in Summer 1996 under the name 'Margarita'. By 1999 
'Margarita' was sold by plant distributors throughout the country. A cultivar release was published in 2001 (Armitage and Garner, 2001).

Successful plant introductions have contributed significantly to the growth and development of new floricultural crops, however, their greatest benefit is the credibility they have brought to the department and university.

Plant patenting. None of the above materials has generated funds for the garden or the University, and recently, the decision was made to pursue a program of patenting new material. The first plant patented was 'Athens Blue Spires' rosemary (Rosmarinus officinalis) (U.S. Plant and Trademark Office, 2000), and the most recent, still in the process, is 'Lemon Sorbet' scabious (Scabiosa). All details are handled by University of Georgia Research Foundation (UGARF). Propagators were selected and royalties are paid to UGARF for distribution. Additional plants are being considered for this program, however, without controlled breeding, the ability to patent plants is limited.

INDUSTRY SUPPORT FOR NEW CROPS FROM UGA. In Summer 1998, a alliance was forged between EuroAmerica Propagators (Bosnall, Calif.) and UGARF to launch a new program for the national introduction of plants from the UGA trial garden. The program, known as Athens Select ${ }^{\mathrm{TM}}$, involves marketing and production of plants recommended for heat and humidity tolerance based on performance data from the gardens. Plants were selected by the propagator and the author for inclusion in the program. They were cleaned of virus and propagated under license from UGARF. Each plant returns \$0.03 to the foundation, $\$ 0.01$ is earmarked for marketing purposes. The first plants were sold under the banner Athens Select $^{\mathrm{TM}}$ in Spring 2000. In Summer 2000, four additional propagators joined the program and will begin selling material under the Athens Select ${ }^{\mathrm{TM}}$ name in Spring 2001. In Summer 2000, taxa were designated AS 2002 and AS 2003 plants for future introduction. The program has the potential for introducing little known material into many markets in the United States, and the potential of generating funding for the trials themselves.

In summary, a trial garden is not to be undertaken lightly. The garden requires a significant commitment of time, funding and personnel. The basic objectives of evaluation, publication and teaching must be attained to justify the use of such capital. However, properly conducted, a university trial ground can be a visible and useful part of the departmental program, as well as bring credibility and funding to the university and department.

\section{Literature cited}

Armitage, A.M. 1992. Mama, somebody's here about your flowers. Greenhouse Grower 10:42,44.

Armitage, A.M. 1994. Coleus; deja vu all over again. Greenhouse Grower 12:52, 54 .

Armitage, A.M. 1995. The rise of the mighty coleus. Greenhouse Grower. 13:77-80.

Armitage, A.M. 2001. University of Georgia trial garden. 13 May 2001, <http// www.uga.edu/ugatrial>.

Armitage, A.M., M. Green, and A. Miller. 1999. The University of Georgia Horticulture Garden, results 1998. Univ. Georgia, Athens, College Agr. Environ. Sci. Spec. Publ. 96.

Armitage, A.M. and J.M. Garner. 2001. Ipomoea batatas 'Margarita'. HortScience 36:178

U.S. Plant and Trademark Office, 2000. United States Patent, Plant 11,552. U.S. Patent and Trademark Office, Wash., D.C. 